\title{
Leukocyte adhesion deficiency
}

INSERM

\section{Source}

INSERM. (1999). Orphanet: an online rare disease and orphan drug data base. Leukocyte adhesion deficiency. ORPHA:2968

Leukocyte adhesion deficiency (LAD) is a primary immunodeficiency characterized by defects in the leukocyte adhesion process, marked leukocytosis and recurrent infections. 